\title{
Management Practices and Feed Supplements on the Growth of Two Chicken Breeds (Gallus Domesticus L.) under Smallholders' Farm Conditions: Case of Rajshahi
}

\author{
M. Saiful Islam ${ }^{*}$, Sharmin Mustari ${ }^{2}$ \\ ${ }^{1}$ Professor, Genetics and Molecular Biology Laboratory, Department of Zoology, University of Rajshahi, \\ Rajshahi 6205, BANGLADESH \\ ${ }^{2}$ Assistant Professor, Genetics and Molecular Biology Laboratory, Department of Zoology, University of \\ Rajshahi, Rajshahi 6205, BANGLADESH \\ *Corresponding Contact: \\ Email: saifulzoo.ru@gmail.com
}

\begin{abstract}
The present study assessed the management practices and feed supplements on growth performance of two common chicken breeds viz., Fayoumi (an exotic) and Sonali (a crossbred) in 10 Upozillas or Police Stations of Rajshahi District. For the collection of experimental data every week, a government, 10 private and 10 backyard smallholders' poultry farms were selected, and the investigation was conducted from January to December 2015. Fourteen such major management practices as feeding, vaccination, biosafety measures, disposal of wastes and dead bodies were considered to rank the farms from excellent (score 5) to unacceptable (score 1) scales. All the parameters showed significant variation $(\mathrm{P}<0.05)$ except room heating, source of water, bio-safety measures, contacts with veterinarians, disposal of excreta, access of wild animals and disease management. The second half of the survey witnessed a relatively better management practices in all farm types. Results on feed supplements and growth performance of both sexes of Fayoumi and Sonali chickens up to 8 weeks with four dietary treatment groups viz., T1 (control), T2 (control + $12500 \mathrm{IU}$ vitamin A (VitA)/kg feed), T3 [control + essential amino acids (EAAs)] and T4 (control + $12500 \mathrm{IU}$ VitA $/ \mathrm{kg}$ feed + EAAs) were promising. Feed conversion ratios (FCR), survivability $(\mathrm{SB} \%$ ) and carcass characteristics (CC) exhibited treatment effects $(\mathrm{P}<0.001)$ but no breed effect with respect to FCR. Conversely, gender effect showed significant variation for all the $\mathrm{CC}(\mathrm{P}<0.05)$ except for breast meat. In contrast, dressing yield, drumstick meat and thigh meat had no treatment effects. It appeared from the present results that strict bio-safety oriented management practices, coupled with the selection of fast growing and heavy laying breeds of chickens and feed supplements at recommended doses could ensure sustainability as well as profitability of the emerging poultry farms in the study area.
\end{abstract}

Keywords: Management practices, feed supplements, growth performance, feed conversion ratio, carcass characteristics, survivability, Bangladesh 


\section{INTRODUCTION}

Poultry is one of the best tools for poverty reduction throughout the world. Smallholders' backyard chicken production is a subsistence activity, providing egg and meat for family consumption and, to some extent, family cash income (Faruque et al., 2009). In comparison to other livestock, poultry requires less investment to start the farming. Persons from lowincome group may also start the business on a small scale. As the Southeast Asian agrobased developing country, poultry is one of the most important sectors for the protein source in Bangladesh (FEB, 2015).

Management practices in poultry sector refer to adequate measures taken by the farm owners to ensure sustainable health and productivity of the poultry birds. In a previous study, Kobbaduzzaman (2000) observed the commercial chicken management and suggested some guidelines for the poultry industry owners in Bangladesh. Subsequently, Hossain \& Ali (2009) suggested the waste management in poultry farms and environmental protection in Bangladesh. Ghosh et al. (2009) also suggested some ideas of practices the bio-security in wet market of Bangladesh in response to highly pathogenic avian influenza or bird flu. A survey was made by Aziz \& Ahmed (2009) on the prevailing status of bio-security in smallholder poultry farms and Ferdous (2009) defined the biosecurity from various angles in poultry farm management which was a key element for protecting the farm from various diseases in the country.

Akidarju et al. (2010) assessed certain poultry management practices and disease recognition by poultry farmers in Nigeria, with the view of improving poultry production. While Amanullah et al. (2010) reviewed types, characteristics and effects of poultry manure on soil properties, yield and quality of crops, nutrient availability, residual effects and the method of composting and its effect on crops. Hamra (2010) demonstrated that proper management during the operation and a feasibility analysis prior to investment is required to maximize profits in poultry farms. Proper management ensures efficient production and good quality products (in terms of meat or eggs) which is accomplished by controlling diseases, maintaining feed efficiency, proper handling of wastes, and proper sanitizing of the poultry house. According to Shamsuddoha (2010), however, improved management practices including vaccination services and antibiotic feed additives plus other inputs and services to the poultry sector are essential for a feasible enterprise.

In several recent studies, however, biosecurity and other preventive measures (Akpabio et al., 2014), management practices coupled with small feed supplement (Getu \& Birhan, 2014), improved chicken and market facilities at village levels (Tsegaye et al., 2014), improvement of health of the rural backyard chicken production (Weyuma et al., 2015), training in poultry husbandry management and facilities for marketing chickens (Moreki et al., 2016) and routine cleanliness and regular workshops on biosecurity management practices organized by the government and relevant agencies (Odemero \& Oghenesuvwe, 2016) have been implicated.

A regular supply of feed is essential for improved productivity in commercial poultry systems where a common recommendation is to use commercially manufactured feed sold as 'pre-mixes' (FAO, 2014). Since poultry birds have high dietary protein requirements, identification of the optimum protein concentration in their diets, and knowledge about birds' requirements for protein and amino acids and their effects on the birds' growth performance and development are essential (Beski et al., 2015). Thus supplementary diets 
with amino acids (Geraert et al., 1987), amino acid formulation and dietary direct-fed microbial supplementation in the poultry feed (Applegate et al., 2009), dietary lysine, methionine and L-arginine (Bonekamp et al., 2010; Rao et al., 2011; Fouad et al., 2012), protein and limiting amino acid levels in pre-starter diets (Farkhoy et al. (2012), digestible lysine levels in diets with and without supplementation of industrial amino acids (de Oliveira et al., 2013), canola oil and vitamin A supplement to the diet (Ahmed et al., 2013), amino acid-balanced diet supplement (Burley et al., 2013), L-threonine supplemented treatment (Abdel-Wareth \& Esmail, 2014), and supplementation of different feed types for different classes of chickens in different seasons (Bekele, 2016) have been reported. Here we report the present status of the management practices and effects of feed supplements with vitamin A (VitA) and essential amino acids (EAAs) on growth performance parameters in terms of feed conversion ratio (FCR), carcass characteristics (CC) and survivability (SB) of two available chicken breeds from a regional government farm, some randomly selected commercial private poultry farms and backyard small households in Rajshahi District, Bangladesh. The findings of the study will enrich our understanding for a better and healthy management of an emerging poultry enterprise in the region.

\section{MATERIALS AND MethodS}

Study area: Ten Upozillas (former Police Stations) of Rajshahi District, namely Baghmara, Boalia, Godagari, Mohonpur, Motihar, Paba, Puthia, Rajpara, Shahmokdum and Tanor, were selected for the study (Plate 1). The main considerations in selecting the study area were as follows: (a) A large number of poultry farms are raised in these areas; (b) No study of this nature was conducted previously; (c) The study areas are wellcommunicated; and (d) Co-operation from the farm owners and managers was highly satisfactory.

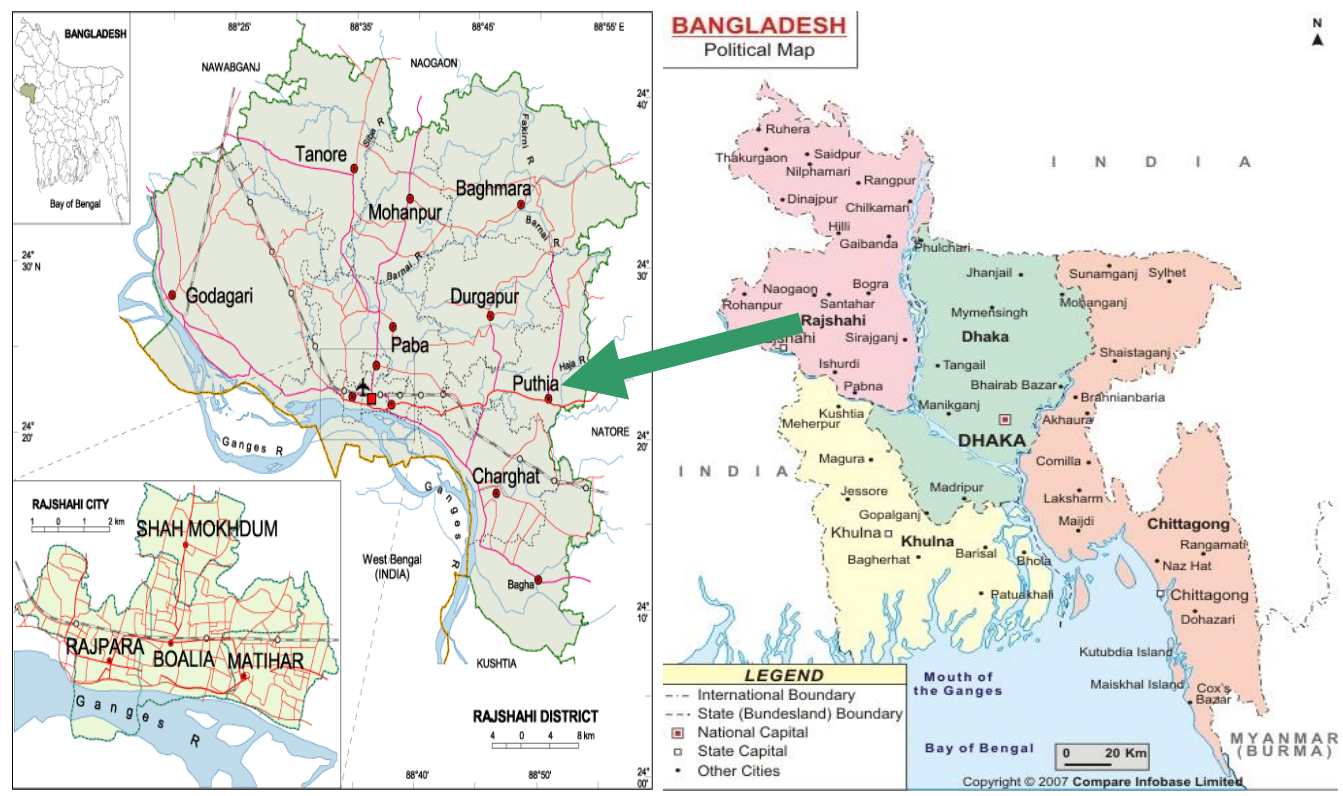

Plate 1 Map of Bangladesh (right) showing the study area (left) Rajshahi District and City

Selection of poultry farms: A total of 61, consisting of one government, 30 private and 30 backyard smallholders' poultry farms were selected for the study. The poultry farm 
owners were interviewed personally and data were collected using an interview schedule of structured questionnaire. The Regional Poultry Farm at Rajabari, the only government poultry farm in Rajshahi, is situated under Godagari Upozilla. In addition, Upozilla-wise and village-based 10 private and 10 backyard poultry farms were selected at random for collecting experimental data

Selection of chicken breeds: Two available and popular chicken breeds in the study area viz., Fayoumi (an exotic breed), and Sonali (a hybrid from Fayoumi $\times$ RIRơ) were selected for the present study.

Frequency of data collection: Weekly visits were made to the selected poultry farms during the study period from January to December 2015. Relevant information on management practices and growth performance of the chickens following supplementary feed treatments were monitored and collected.

\section{Parameters Studied}

Management practices: Using a 5-scale scoring system, 14 major management practices as room heating $(\mathrm{RH})$, source of water (SW), use of disinfectant (UD), vaccination (VC), biosafety measures $(\mathrm{BM})$, contacts with vets $(\mathrm{CV})$, boundary walls $(\mathrm{BW})$, disposal of excreta (DE) and dead bodies (DD), access to wild animals (AW), disease management (DM), human residence (HR), chicken transportation (CT) and feeding management (FM) were considered to rank the farms under study, where score 5 was considered excellent, 4 as good, 3 as satisfactory, 2 as not good and 1 as unacceptable.

Feed supplements: Experimental Fayoumi and Sonali chickens of both sexes were rerared at farm conditions with a rearing period of 8 weeks or 56 days. The chicken breeds were divided into four treatment groups viz., $\mathrm{T}_{1}$ (control), $\mathrm{T}_{2}, \mathrm{~T}_{3}$ and $\mathrm{T}_{4}$. The control group $\mathrm{T}_{1}$ was provided with commercial ration (Table 1), group $\mathrm{T}_{2}$ with vitamin $\mathrm{A}$ (VitA), group $\mathrm{T}_{3}$ with essential amino acids (EAAs) and group $\mathrm{T}_{4}$ both VitA and EAAs (Table 2).

Table 1 Nutrient ingredients and chemical composition of the control diet

\begin{tabular}{|lccc|}
\hline Nutrient Ingredients (\%) & $\begin{array}{c}\text { Starter } \\
\text { (0-20 days) }\end{array}$ & $\begin{array}{c}\text { Grower } \\
(\mathbf{2 1 - 4 0} \text { days) }\end{array}$ & $\begin{array}{c}\text { Finisher } \\
\text { (41-56 days) }\end{array}$ \\
\hline Moisture & $10-11$ & $10-11$ & $10-11$ \\
Crude protein (at least) & $22-23$ & $21-22$ & $20-21$ \\
Crude fibre & $3-4$ & $3-4$ & $3-4$ \\
Fat & $5-6$ & $6-7$ & $7-8$ \\
Ash & $7-8$ & $7-8$ & $8-9$ \\
Metabolic energy & 3000 & 3100 & 3200 \\
(kcal/kg) & 1.00 & 0.95 & 0.98 \\
Calcium (at least) & 0.45 & 0.45 & 0.45 \\
Phosphorus (at least) & 0.75 & 0.85 & 0.90 \\
Vitamin-Mineral premix & 1.20 & 1.10 & 1.00 \\
Lysine (at least) & 0.45 & 0.48 & 0.48 \\
Methionine (at least) & & & \\
\hline
\end{tabular}

Produced and supplied by the National Feed Mills Limited, Gazipur, Bangladesh 
Table 2 Essential amino acids and vitamin A supplemented to the treated diets

\begin{tabular}{|lccc|}
\hline \multirow{2}{*}{ Nutrients (\%) } & \multicolumn{3}{c|}{ Age of chickens in days } \\
\cline { 2 - 4 } & $\mathbf{0 - 2 0}$ & $\mathbf{2 1 - 4 0}$ & $\mathbf{4 1 - 5 6}$ \\
\hline Methionine & 0.50 & 0.38 & 0.32 \\
Lysine & 1.10 & 1.00 & 0.85 \\
Threonine & 0.80 & 0.74 & 0.68 \\
Tryptophan & 0.20 & 0.18 & 0.16 \\
Isoleucine & 0.80 & 0.73 & 0.62 \\
Arginine & 1.25 & 1.10 & 1.00 \\
Valine & 0.90 & 0.82 & 0.70 \\
Vitamin $\mathrm{A}^{1}$ & $12500 \mathrm{IU}$ & $12500 \mathrm{IU}$ & $12500 \mathrm{IU}$ \\
\hline
\end{tabular}

${ }^{*}$ Recommended by NRC (1994); ${ }^{1}$ per kg diet

Processing of chicken: For recording carcass characteristics, the experimental chickens were slaughtered. Prior to slaughtering and to facilitate proper bleeding, feed was withdrawn and drinking water was supplied ad libitum for $12 \mathrm{hrs}$. After complete bleeding, the slaughtered birds were immersed in pre-warmed water at $70{ }^{\circ} \mathrm{C}$ for 30 to 60 seconds in order to loosen the feathers of the carcases. Final processing was performed by removal of the head, shank, viscera, oil gland, kidneys and lungs. Heart and liver were removed from the remaining viscera by cutting them loose. As soon as these were removed, the gall bladder was removed from the liver and the pericardial sac and arteries were excised from the heart. The gizzard was removed by cutting it loose in front of the proventiculus by cutting both incoming and outgoing digestive tract. Finally, it was split open with knife, emptied, washed and the lining was removed by hand (Jones, 1984).

Layout 1 Layout showing the experimental chicken, supplementary feed treatment groups and their replications

\begin{tabular}{|c|c|c|c|c|c|c|}
\hline \multirow{2}{*}{ Breeds } & \multirow{2}{*}{ Sexes } & \multirow{2}{*}{$\begin{array}{c}\text { Treatment } \\
\text { groups* }\end{array}$} & \multicolumn{3}{|c|}{ Replications } & \multirow{2}{*}{ Grand total } \\
\hline & & & 1 & 2 & 3 & \\
\hline \multirow{4}{*}{ Sonali } & \multirow{4}{*}{ Male } & $\mathrm{T}_{1}$ & 16 & 16 & 16 & \multirow[b]{5}{*}{192} \\
\hline & & $\mathrm{T}_{2}$ & 16 & 16 & 16 & \\
\hline & & $\mathrm{T}_{3}$ & 16 & 16 & 16 & \\
\hline & & $\mathrm{T}_{4}$ & 16 & 16 & 16 & \\
\hline & & Group $=4$ & $=64$ & $=64$ & $=64$ & \\
\hline \multirow{4}{*}{ Sonali } & \multirow{4}{*}{ Female } & $\mathrm{T}_{1}$ & 16 & 16 & 16 & \multirow[b]{5}{*}{192} \\
\hline & & $\mathrm{T}_{2}$ & 16 & 16 & 16 & \\
\hline & & $\mathrm{T}_{3}$ & 16 & 16 & 16 & \\
\hline & & $\mathrm{T}_{4}$ & 16 & 16 & 16 & \\
\hline & & Group $=4$ & $=64$ & $=64$ & $=64$ & \\
\hline \multirow{4}{*}{ Fayoumi } & \multirow{4}{*}{ Male } & $\mathrm{T}_{1}$ & 16 & 16 & 16 & \multirow[b]{5}{*}{192} \\
\hline & & $\mathrm{T}_{2}$ & 16 & 16 & 16 & \\
\hline & & $\mathrm{T}_{3}$ & 16 & 16 & 16 & \\
\hline & & $\mathrm{T}_{4}$ & 16 & 16 & 16 & \\
\hline & & Group $=4$ & $=64$ & $=64$ & $=64$ & \\
\hline \multirow{4}{*}{ Fayoumi } & \multirow{4}{*}{ Female } & $\mathrm{T}_{1}$ & 16 & 16 & 16 & \multirow{6}{*}{$\frac{192}{768}$} \\
\hline & & $\mathrm{T}_{2}$ & 16 & 16 & 16 & \\
\hline & & $\mathrm{T}_{3}$ & 16 & 16 & 16 & \\
\hline & & $\mathrm{T}_{4}$ & 16 & 16 & 16 & \\
\hline & & Group $=4$ & $=64$ & $=64$ & $=64$ & \\
\hline \multicolumn{2}{|c|}{ Grand Total } & Group $=16$ & 256 & 256 & 256 & \\
\hline
\end{tabular}

$\mathrm{T}_{1}=$ Control; $\mathrm{T}_{2}=$ Control + VitA $(12500 \mathrm{IU} / \mathrm{kg}$ diet $) ; \mathrm{T}_{3}=$ Control + EAAs and $\mathrm{T}_{4}=$ Control + VitA + EAAs. 
Growth performance: Effects of chicken breeds, sexes and supplementary feed treatments on three vital growth performance parameters viz., feed conversion ratio (FCR), carcass characteristics (CC) and survivability (SB) were studied (Layout 1).

Feed conversion ratio (FCR): It is the ability of the chickens to turn feed mass into body mass. FCR was therefore calculated by using the formula: FCR $=$ feed intake in $\mathrm{g} \div$ average daily gain in $\mathrm{g}$.

Carcass characteristics (CC): Carcass characteristics were measured in terms of total meat $(\mathrm{TM})$, breast meat (BM), dark meat (DRM), drumstick meat (DM), wing meat (WM) and thigh meat (THM). All the CC data were converted into percentage of respoctive live weight (LW) prior to statistical analysis. Dressing yield (DY) of the birds were determined by dividing the carcass weight with its live weight multiplied by 100 and expressed in percentages.

Survivability (SB\%): SB\% of the experimental chickens was calculated by the number of surviving birds from day-old chicks to 56 day-old individuals multiplied by 100 .

\section{Statistical Analyses}

Data on management practices and feed supplement experiments were compiled, tabulated and analyzed in accordance with the objectives of the research. Analysis of variance (ANOVA), t-test and significant differences among treatment means were identified by least significant difference (LSD) tests. SPSS for Windows (version 19.0) were used to analyze the data.

\section{RESULTS}

\section{Management practices of the poultry farms}

A detailed account of the management practices of the poultry farms under study is presented in terms of 14 well-defined parameters and estimated mean values of a 5-scale score system (Fig. 1). Data revealed that the government farm scored the highest $(3.29 \pm 0.43)$ in comparison with the private $(2.56 \pm 0.30)$ and backyard $(2.35 \pm 0.11)$ poultry farms during the first half of the investigation.

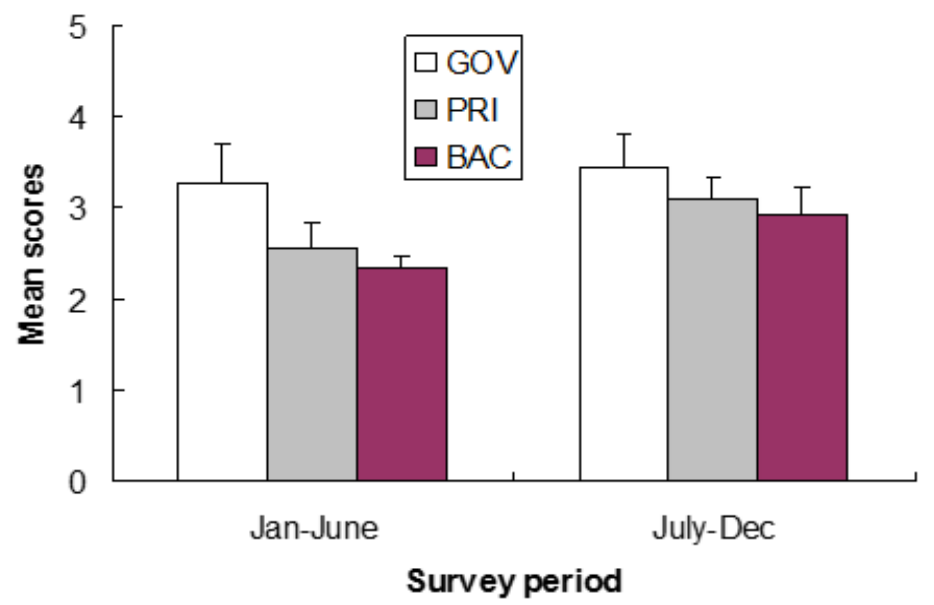

Figure 1 Mean scores for management practices in the poultry farms (GOV= government; PRI= private; $B A C=$ backyard) during January-December, 2015 in Rajshahi, Bangladesh 
During the second half of the survey, however, the overall management practices of all the farms improved considerably where the government, private and backyard farms scored $3.43 \pm 0.40,3.09 \pm 0.26$ and $2.91 \pm 0.32$, respectively. The differences in mean scores for management practices between the poultry farms were significant both during JanuaryJune $\left(\mathrm{F}_{2,62}=4.13 ; \mathrm{P}<0.05\right)$ and July-December $\left(\mathrm{F}_{2,62}=3.76 ; \mathrm{P}<0.5\right)$. This was obviously a good indication that the biosafety awareness of the poultry farmers increased during the second half of the survey period.

\section{Feed supplement and growth performance}

Feed conversion ratios (FCR): The breed-wise difference in FCR between the FAY and SON chickens during the rearing period of eight weeks was not a significant one (Table 3) but that between males and females over the same period was found to be significant except for the $3^{\text {rd }}, 4^{\text {th }}$ and $8^{\text {th }}$ weeks of rearing (Table 4 ). Treatment-wise difference in FCR, on the other hand, was found to be highly significant throughout the rearing period. The findings suggest that both FAY and SON chickens had predominantly almost similar FCR but males and females of the chicken breeds showed differences in their FCR during most of their rearing period. The differences in FCR between feed supplemented treatment groups were significant $(\mathrm{P}<0.01$ and $\mathrm{P}<0.001)$, indicating that the trait was highly influenced by the addition of VitA and EAAs supplements to the regular poultry feed.

Carcass characteristics: Breed-wise variation in carcass characteristics between FAY and SON chickens (Plates 2 and 3) revealed that LW, DKM, DM, WM and THM differed significantly between breeds (Table 5). Moreover, differences in carcass characteristics between male and female chickens were also found to be significant except for BM (Table 6). Feed supplement experiment showed significant differences in CC between the treatment groups except for DY, DM and THM. The results indicated that there existed significant differences in certain CC between the breed and gender of the chickens which were also influenced by the administration of feed supplements in the experimental chickens. In addition, further analysis revealed that majority of the CC parameters such as LW, TM, BM, DKM and WM differed significantly between the treatment groups, suggesting that the economic traits of the poultry carcass could be improved by the addition of recommended concentrations of VitA and EAAs to the regular poultry feed.

Table 3 Breed-wise feed conversion ratio (FCR) in different feed supplemented treatment groups of chickens during the rearing period of eight weeks

\begin{tabular}{|c|c|c|c|c|c|c|c|c|}
\hline RP (week) & $1^{\text {st }}$ & $2^{\text {nd }}$ & $3^{\text {rd }}$ & $4^{\text {th }}$ & $5^{\text {th }}$ & $6^{\text {th }}$ & $7^{\text {th }}$ & $8^{\text {th }}$ \\
\hline FCR $^{*}$ & $\begin{array}{c}1.63 \pm 0.20 \\
(1.55 \pm 0.21)\end{array}$ & $\begin{array}{c}1.88 \pm 0.34 \\
(1.97 \pm 0.38)\end{array}$ & $\begin{array}{c}3.32 \pm 0.56 \\
(3.14 \pm 0.59)\end{array}$ & $\begin{array}{c}3.96 \pm 0.69 \\
(3.94 \pm 0.60)\end{array}$ & $\begin{array}{c}3.68 \pm 0.60 \\
(3.80 \pm 0.53)\end{array}$ & $\begin{array}{c}3.78 \pm 0.47 \\
(3.57 \pm 0.40)\end{array}$ & $\begin{array}{c}3.42 \pm 0.34 \\
(3.29 \pm 0.29)\end{array}$ & $\begin{array}{c}2.77 \pm 0.24 \\
(2.72 \pm 0.28)\end{array}$ \\
\hline \multirow{2}{*}{$\mathrm{t}$-values } & 1.434 & -.858 & 1.066 & 0.151 & -.763 & 1.593 & 1.388 & 0.747 \\
\hline & 1.434 & -.858 & 1.066 & 0.151 & -.763 & 1.593 & 1.388 & 0.747 \\
\hline Sig. Level & ns & ns & ns & ns & ns & ns & ns & ns \\
\hline
\end{tabular}

FCR measured as per $g$ feed per g gain; *Mean \pm SD of FCR derived from SON and FAY (in parentheses) chickens breeds reared up to rearing period (RP) of eight weeks; all $t$-values were at $46 \mathrm{df}$.; $\mathrm{ns}=$ not significant. 
Table 4 Gender-wise feed conversion ratio (FCR) in different feed supplemented treatment groups of chickens during the rearing period of eight weeks

\begin{tabular}{|c|c|c|c|c|c|c|c|c|}
\hline $\mathrm{RP}$ (week) & $1^{\text {st }}$ & $2^{\text {nd }}$ & $3^{\text {rd }}$ & $4^{\text {th }}$ & $5^{\text {th }}$ & $6^{\text {th }}$ & $7^{\text {th }}$ & $8^{\text {th }}$ \\
\hline \multirow{2}{*}{ FCR $^{*}$} & $1.51 \pm 0.20$ & $1.68 \pm 0.23$ & $3.26 \pm 0.70$ & $3.78 \pm 0.54$ & $3.44 \pm 0.43$ & $3.50 \pm 0.39$ & $3.21 \pm 0.27$ & $2.80 \pm 0.22$ \\
& $(1.67 \pm 0.19)$ & $(2.17 \pm 0.28)$ & $(3.21 \pm 0.43)$ & $(4.12 \pm 0.69)$ & $(4.04 \pm 0.52)$ & $(3.85 \pm 0.43$ & $(3.50 \pm 0.30)$ & $(2.68 \pm 0.29)$ \\
\hline \multirow{2}{*}{ t-values } & -2.773 & -6.695 & 0.331 & -1.908 & -4.278 & -2.911 & -3.623 & 1.628 \\
& -2.773 & -6.695 & 0.331 & -1.908 & -4.278 & -2.911 & -3.623 & 1.628 \\
\hline Sig. Level & $*$ & $* * *$ & ns & ns & $* * *$ & $* *$ & $* *$ & ns \\
\hline
\end{tabular}

FCR measured as per $\mathrm{g}$ feed per $\mathrm{g}$ gain; ${ }^{*}$ Mean $\pm \mathrm{SD}$ of feed conversion ratio (FCR) derived from males and females (in parentheses) chickens of SON and FAY breeds reared up to rearing period $(\mathrm{RP})$ of eight weeks; all $\mathrm{t}$-values were at $46 \mathrm{df} .{ }^{*}=5 \%,{ }^{* *}=1 \%,{ }^{* * *}=0.01 \%$ level of significance and ns $=$ not significant.

Table 5 Breed-wise carcass characteristics in different feed supplemented treatment groups of chickens during the rearing period of eight weeks

\begin{tabular}{|c|c|c|c|c|c|c|c|c|}
\hline Breeds & LW $(\mathrm{g})$ & DY (\%) & TM & BM & DKM & DM & WM & THM \\
\hline \multirow{2}{*}{ FAY } & 623.38 & 57.67 & 37.57 & 12.92 & 26.04 & 7.64 & 3.88 & 10.70 \\
& \pm 64.14 & \pm 3.24 & \pm 1.11 & \pm 0.97 & \pm 0.66 & \pm 0.59 & \pm 0.47 & \pm 0.62 \\
\hline \multirow{2}{*}{ SON } & 580.12 & 57.51 & 38.14 & 12.47 & 27.13 & 8.13 & 3.36 & 11.69 \\
& \pm 59.68 & \pm 1.75 & \pm 1.87 & \pm 0.78 & \pm 1.54 & \pm 0.58 & \pm 0.27 & \pm 1.02 \\
\hline t-values & 2.419 & 0.207 & 1.286 & 1.792 & 3.165 & 2.939 & 4.777 & 4.074 \\
\hline Sig. Level & $*$ & $\mathrm{~ns}$ & $\mathrm{~ns}$ & $\mathrm{~ns}$ & $* *$ & $* *$ & $* * *$ & $* * *$ \\
\hline
\end{tabular}

Mean \pm SD values of the carcass characteristics in FAY (Fayoumi) and SON (Sonali) chickens reared in different treatment groups; $\mathrm{LW}=$ live weight, DY= dressing yield, $\mathrm{TM}=$ total meat, $\mathrm{BM}=$ breast meat, $\mathrm{DKM}=$ dark meat, $\mathrm{DM}=$ drumstick meat, $\mathrm{WM}=$ wing meat, $\mathrm{THM}=$ thigh meat; ${ }^{*}=\mathrm{P}<0.05,{ }^{* *}=\mathrm{P}<0.01,{ }^{* * *}=\mathrm{P}<0.001$; ns $=$ not significant; all $\mathrm{t}$-values were at $46 \mathrm{df}$.

Table 6 Gender-wise carcass characteristics in different feed supplemented treatment groups of chickens during the rearing period of eight weeks

\begin{tabular}{|c|c|c|c|c|c|c|c|c|}
\hline Genders & LW $(\mathrm{g})$ & DY (\%) & TM & BM & DKM & DM & WM & THM \\
\hline \multirow{2}{*}{ Male } & 638.17 & 59.44 & 38.39 & 12.52 & 27.36 & 8.41 & 3.33 & 11.97 \\
& \pm 56.25 & \pm 1.85 & \pm 1.66 & \pm 0.77 & \pm 1.32 & \pm 0.34 & \pm 0.26 & \pm 0.74 \\
& & & & & & & & \\
\multirow{4}{*}{ Female } & 565.33 & 55.74 & 37.32 & 12.87 & 25.80 & 7.36 & 3.91 & 10.42 \\
& \pm 52.15 & \pm 1.74 & \pm 1.25 & \pm 0.99 & \pm 0.66 & \pm 0.34 & \pm 0.43 & \pm 0.36 \\
\hline t-values & 4.652 & 7.122 & 2.510 & 1.373 & 5.187 & 10.689 & 5.684 & 9.258 \\
\hline Sig. Level & $* * *$ & $* * *$ & $*$ & ns & $* * *$ & $* * *$ & $* * *$ & $* * *$ \\
\hline
\end{tabular}

Mean \pm SD values of the carcass characteristics in male and female (in parentheses) of FAY (Fayoumi) and SON (Sonali) chickens reared in different treatment groups; LW= live weight, $\mathrm{DY}=$ dressing yield, $\mathrm{TM}=$ total meat, $\mathrm{BM}=$ breast meat, $\mathrm{DKM}=$ dark meat, $\mathrm{DM}=$ drumstick meat, $\mathrm{WM}=$ wing meat, $\mathrm{THM}=$ thigh meat; $^{*}=\mathrm{P}<0.05,{ }^{* * *}=\mathrm{P}<0.001 ; \mathrm{ns}=$ not significant; all t-values are at $46 \mathrm{df}$. 


\section{Meat features}

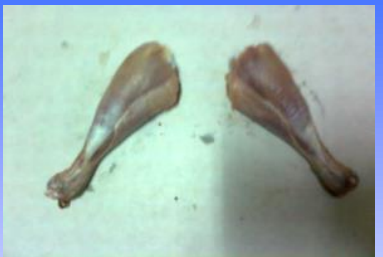

Drumstick meat (male)

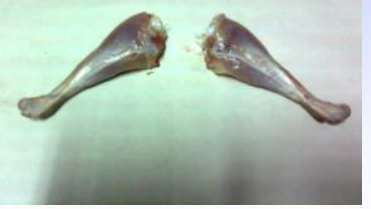

Drumstick meat (female)

\section{Fayoumi (Male and Female)}

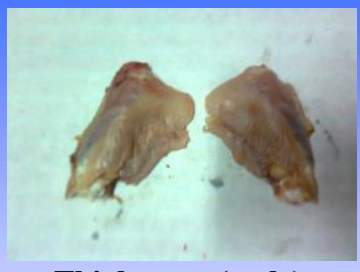

Thigh meat (male)

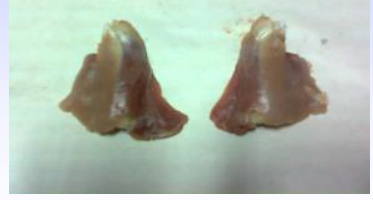

Thigh meat (female)

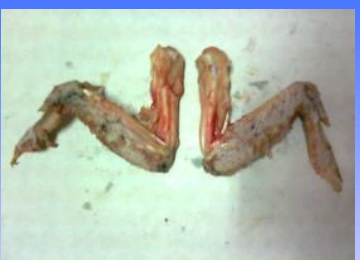

Wing meat (male)

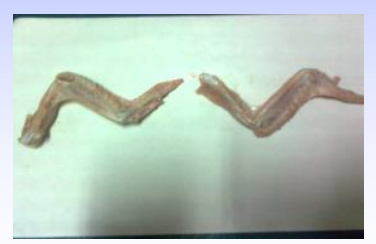

Wing meat (female)

Plate 2 Carcass characteristics of Fayoumi (males above, females below)

\section{Meat features}

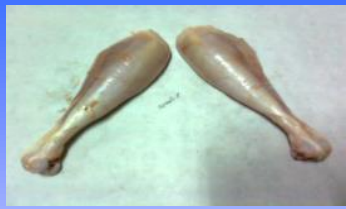

Drumstick meat (male)

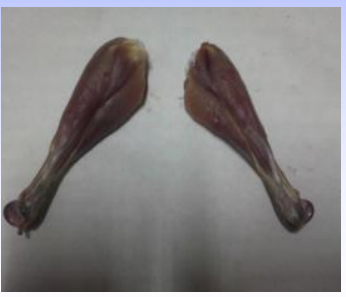

Drumstick meat (female)

\section{Sonali (Male and Female)}

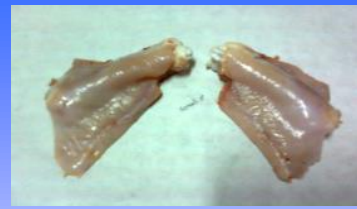

Thigh meat (male)

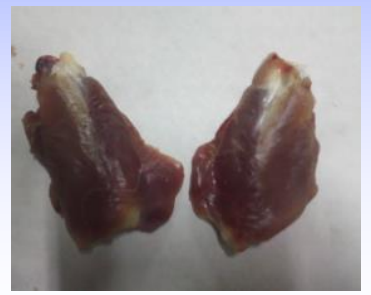

Thigh meat (female)

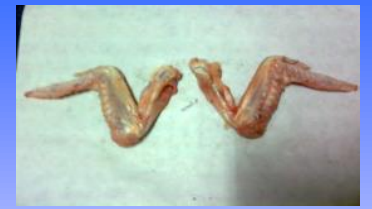

Wing meat (male)

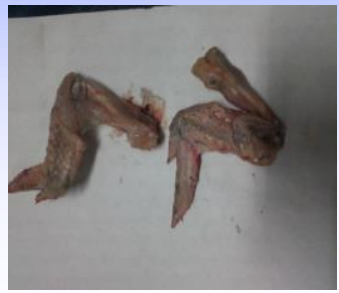

Wing meat (female)

Plate 3 Carcass characteristics of Sonali (males above, females below)

Survivability (SB\%): Treatment-wise survivability percentage data during eight weeks' rearing period are presented in Table 7 . The highest survivability of chickens $(85.08 \pm 0.37)$ was recorded in the control feed experiment $\left(\mathrm{T}_{1}\right)$. Compared to the control, $\mathrm{T}_{2}, \mathrm{~T}_{3}$ and $\mathrm{T}_{4}$ groups showed respectively $84.70 \pm 0.22,84.61 \pm 0.15$ and $84.00 \pm 0.00$ percent survivability of the chickens under study. Even though there was a slight variation in $\mathrm{SB} \%$, the overall treatment effect was significant $\left(\mathrm{F}_{3,38}=30.82 ; \mathrm{P}<0.001\right)$, suggesting that untreated chickens survived better that those of the treated ones. Feed supplement, therefore, slightly affected the survivability of the experimental chickens. 
Table 7 Survivability of the experimental chickens in different feed supplemented treatment groups during the rearing period of eight weeks

\begin{tabular}{|c|c|c|c|c|c|c|c|c|c|}
\hline Treatment groups $^{*}$ & $1^{\text {st }}$ & $2^{\text {nd }}$ & $3^{\text {rd }}$ & $4^{\text {th }}$ & $5^{\text {th }}$ & $6^{\text {th }}$ & $7^{\text {th }}$ & $8^{\text {th }}$ & SB\% \\
\hline & 84.25 & 84.92 & 85.00 & 85.17 & 85.33 & 85.33 & 85.33 & 85.33 & 85.08 \\
$\mathrm{~T}_{1}$ & \pm 0.45 & \pm 0.79 & \pm 0.74 & \pm 0.83 & \pm 0.65 & \pm 0.65 & \pm 0.65 & \pm 0.65 & $\pm 0.37^{\text {a }}$ \\
\hline & 84.25 & 84.50 & 84.67 & 84.83 & 84.83 & 84.83 & 84.83 & 84.83 & 84.70 \\
$\mathrm{~T}_{2}$ & \pm 0.45 & \pm 0.52 & \pm 0.49 & \pm 0.39 & \pm 0.39 & \pm 0.39 & \pm 0.39 & \pm 0.39 & $\pm 0.22^{\mathrm{b}}$ \\
\hline & 84.25 & 84.58 & 84.67 & 84.67 & 84.67 & 84.67 & 84.67 & 84.67 & 84.61 \\
$\mathrm{~T}_{3}$ & \pm 0.45 & \pm 0.51 & \pm 0.65 & \pm 0.65 & \pm 0.65 & \pm 0.65 & \pm 0.65 & \pm 0.65 & $\pm 0.15^{\text {bc }}$ \\
\hline & 84.00 & 84.00 & 84.00 & 84.00 & 84.00 & 84.00 & 84.00 & 84.00 & 84.00 \\
$\mathrm{~T}_{4}$ & \pm 0.00 & \pm 0.00 & \pm 0.00 & \pm 0.00 & \pm 0.00 & \pm 0.00 & \pm 0.00 & \pm 0.00 & $\pm 0.00^{\text {d }}$ \\
\hline F-values & & & & & & & & & 30.82 \\
\hline Sig. Level & & & & & & & & & $* * *$ \\
\hline
\end{tabular}

$\mathrm{SB} \%=$ survivability percentages; $\mathrm{T}_{1}$ (control), $\mathrm{T}_{2}$ (control $+12500 \mathrm{IU}$ VitA $/ \mathrm{kg}$ feed), $\mathrm{T}_{3}$ (control + EAAs) and their combinations $\mathrm{T}_{4}$ (control +12500 IU VitA $/ \mathrm{kg}$ feed + EAAs); all F-values were at 3, $28 \mathrm{df} ;{ }^{* * *}=\mathrm{P}<0.001$.

\section{DISCUSSION}

The poultry industry might face serious constraints due to management practices, such as bad housing, inadequate vaccination and high mortality possibly due to multiple antibiotics resistance resulting from multiple antibiotics usage (Akidarju et al., 2010). But proper management ensures efficient production and good quality products, in terms of meat or eggs, which is accomplished by controlling diseases, maintaining feed efficiency, proper handling of wastes, and proper sanitizing of the poultry house (Hamra, 2010). It has been demonstrated by Olumayowa \& Abiodun (2011) that poultry waste management and effective monitoring services could reduce environmental pollution and incidence of disease outbreaks. Karabozhilova et al. (2012) pointed out that a lack of avian and zoonotic disease knowledge and awareness among the owners has implications for disease control and highlights the need for improved communication between owners, authorities and veterinarians; whereas Musa et al. (2012) suggested that careful selection, adequate management and proper storage and utilization of poultry litter are of paramount importance to reduce environmental pollution, disease spread and economic losses associated with poultry litter. These corroborate to the present findings on management practices in the study area.

In a recent study in Nigeria, Akpabio et al. (2014) noted that poultry management systems included, among others, source, number and age of birds, sources of feed and drinking water, presence of foot bath, disposal of dead birds, presence of pests, other animals on the farm, record of disease outbreak and control measures to prevent such outbreaks. Getu \& Birhan (2014), on the other hand, observed in Ethiopia that extensive production systems was the dominant management practices of chicken with small feed supplementation. The study emphasized on availing production technologies including breeding systems, organizing input supply system for chicks, feed, vaccines and veterinary drugs for chicken and eggs. Another study in Ethiopia by Tsegaye et al. (2014) reported on the management practices and marketing systems of village chicken production where $97.8 \%$ of the respondents provided additional feed supplements, provided mostly three times per day. Through introducing improved chicken management practices and market facility at village levels, Tsegaye et al. (2014) concluded that the farmers' benefit could be enhanced. 
In well agreement with the aforesaid findings, an improved management practices in the second half of the present investigation witnessed better performance of the chicken breeds under study.

The mortality of chicken was observed as major constraint to backyard chicken management at village levels in Ethiopia, where efforts should be geared towards the improvement of health and management practices to improve rural backyard chicken production (Weyuma et al., 2015). Moreki et al. (2016) reported that in order to increase the benefits of rearing indigenous (Tswana) chickens, the farmers should be trained in general poultry husbandry management and also be encouraged to form associations to assist them in marketing chickens, because Tswana chickens play an important role in food security at household level of the rural populace in Botswana. In Nigeria, Odemero \& Oghenesuvwe (2016) recorded a mortality rate of $12 \%$ and indicated that litter replacement frequency, stocking density (0.87), available biosecurity infrastructure and routine cleanliness were significant biosecurity factors. Similar to the later result, mortality of 15$16 \%$ chickens was estimated in the present study.

Poultry birds have high dietary protein requirements, and therefore identification of the optimum protein concentration in their diets, for either maximizing performance or profit, requires more knowledge about birds' requirements for protein and amino acids and their effects on the birds' growth performance and development. Geraert et al. (1987) showed that supplementary diets with alanine $(2 \mathrm{~g} / \mathrm{kg})$, threonine $(2 \mathrm{~g} / \mathrm{kg})$, glutamic acid $(5 \mathrm{~g} / \mathrm{kg})$ and arginine $(5 \mathrm{~g} / \mathrm{kg}$ ) improved feed conversion ratios (FCR) in genetically lean and fat chickens of 4-7 week of age. Mengesha et al. (2011) conducted a study in Ethiopia where $98 \%$ of farmers were supplementing extra feeds and water for their chickens to keep them economically productive. Farkhoy et al. (2012) demonstrated that chicken diets with 1\% methionine + cysteine caused optimal performance. de Oliveira et al. (2013) assessed the effects of digestible lysine levels in poultry diets with and without supplementation of industrial amino acids on performance and fat deposition in the carcass of broilers in the starter phase where the levels of 13.0 and $14.0 \mathrm{~g} / \mathrm{kg}$ digestible lysine provided the best performance. According to a FAO (2014) report, commercially manufactured 'pre-mixes' usually contain protein, vitamins and minerals, to which basal feed ingredient(s) like maize or corn, wheat, rice, oat and millet, and tubers such as cassava, yam, potatoes or plantains is added as necessary. Feeding supplementary diets to chicks, especially at an earlier age, can assist early gut development and digestive physiology, and improve their growth performance as well as immunity (Beski et al., 2015). In Ethiopia, farmer's practices of supplementation of different feed types for different classes of chickens in different seasons have been studied by Bekele (2016), who identified that lack of awareness, cost of feed, lack of feed and feed ingredients were major problems of supplementation. The present feed supplements with VitA and seven EAAs were very promising in terms of feed conversion ratio, carcass characteristics and survivability of the experimental chicken breeds.

\section{Conclusions}

The present report assessed the prevailing management practices and feed supplemented growth performance of Fayoumi and Sonali chickens in Rajshahi District, Bangladesh. Compared to the first half of the experiment (January-June, 2015), the mean scores for management practices in all three categories of the poultry farms improved in the second half (July-December, 2015), which in turn, decreased the disease prevalence parameters and mortality in the selected poultry farms under study. The feed supplement 
experiments with VitA and seven EAAs showed promising results in terms of feed conversion ratio (FCR), carcass characteristics (CC) and survivability (SB\%) of the Fayoumi and Sonali chickens. It is therefore concluded that strict bio-safety oriented management practices, appropriate vaccinations throughout the rearing seasons and recommended feed supplement, coupled with the selection of fast growing and heavy laying breeds of chickens, would ensure sustainability as well as profitability of the emerging poultry farms in the study area.

\section{ACKNOWLEDGEMENTS}

We express our gratefulness to Drs. Susanta Kumar Kundu and Ripon Kumar Dutta, Research Assistants, whose meticulous collections of field data and information enriched the contents and findings of the present study. Sincere co-operation and assistance received from the Resource Personnel, Supervisors and Managers of the Government and private poultry farms, and owners of the backyard smallholders are also thankfully acknowledged. This work was funded by the University of Rajshahi Research Grant Programme through the Faculty of Life and Earth Sciences, University of Rajshahi, Bangladesh.

\section{REFERENCES}

Abdel-Wareth, A.A.A. \& Esmail, Z.S.H. 2014. Some productive, egg quality and serum metabolic profile responses due to L-threonine supplementation to laying hen diets. Asian J. Poult. Sci. 8(3): 75-81.

Ahmad, S., Ahsan-ul-Huq, Yousaf, M., Kamran, Z., Ata-ur-Rahman, Suhail, M.U. \& Ahmad, H.A. 2013. Effect of canola oil and vitamin A on egg characteristics and egg cholesterol in laying hens during hot summer months. Pakistan Vet. J. 33(3): 346-349.

Akidarju, M.S., Onyemaechi, E.G. \& Dauda, M.G. 2010. An assessment of some poultry management practices and disease recognition by poultry farmers in Maiduguri arid zone, Nigeria. World's Poult. Sci. J. 66: 285-296.

Akpabio, U., Kwaga, J.K.P., Kabir, J., Umoh, V.J. \& Otalu, O. Jr. 2014. Assessment of some poultry management practices in Kaduna State, Nigeria. World J. Pub. Health Sci. 3(1): 1-4.

Amanullah, M.M., Sekar, S. \& Muthukrishnan, P. 2010. Prospects and potential of poultry manure. Asian J. Plant Sci. 9: 172-182.

Applegate, T.J., Onyango, E.M., Angel, R. \& Powers, W.J. 2009. Effect of amino acid formulation and dietary direct-fed microbial supplementation on egg production and egg characteristics in laying hens. J. Appl. Poult. Res. 18: 552-561.

Aziz, M.A. \& Ahmed, S.U. 2009. Biosecurity in poultry farm management. $6^{\text {th }}$ International Poultry Show and Seminar, WPSA-BB, p.223-227.

Bekele, B. 2016. Assessment of locally available poultry feeds, feeding practices and health in Sidama zone and Halaba special Woreda in SNNPR. J. Biol. Agric. Healthcare 6(7): 104-110.

Beski, SSM, Swick, RA \& Iji, PA. 2015. Specialized protein products in broiler chicken nutrition: A review. Anim. Nutr. 1: 45-53.

Bonekamp, R.P.R.T., Lemme, A., Wijtten, P.J.A. \& Sparla, J.K.W.M. 2010. Effects of amino acids on egg number and egg mass of brown (heavy breed) and white (light breed) laying hens. Poult. Sci. 89: 522-529.

Burley, H.K., Patterson, P.H. \& Elliot, M.A.2013. Effect of a reduced crude protein, amino acidbalanced diet on hen performance, production costs, and ammonia emission in a commercial laying hen flock. J. Appl. Poult. Res. 22: 217-228. 
de Oliveira, W.P, de Oliveira, R.F.M., Donzele, J.L., Albino, J.F.T., Campos, P.H.R.F., Balbino, E.M., de Assis Maia, A.P. \& Pastore, S.M. 2013. Lysine levels in diets for broilers from 8 to 21 days of age. R. Bras. Zootec. 42(12) 869-878.

FAO (Food and Agricultural Organization) 2014. Decision Tools for Family Poultry Development. FAO Animal Production and Health Guidelines No. 16. Rome, Italy. 123 pp.

Farkhoy, M., Modirsanei, M., Ghavidel, O., Sadegh, M. \& Jafarnejad, S. 2012. Evaluation of protein concentration and limiting amino acids including lysine and Met + Cys in prestarter diet on performance of broilers. Vet. Med. Int. Article ID 394189, 7 pages. doi:10.1155/2012/394189.

Faruque, M.O., Khan, M.Y.A. \& Asaduzzaman, M. 2009. Poultry genetics and breeding in Banglaesh: past, present and future. $6^{\text {th }}$ International Poultry Show and Seminar, WPSA-BB, p.163-167.

FEB (The Financial Express Bangladesh) 2015. Poultry could help end Bangladesh hunger. 21 January 2015. PoultrySite News Desk.

Ferdous, K. 2009. Current status of bio-security in small holder poultry farms in Mymensingh. MS in Pathology, Dept. of Veterinary Pathology, Bangladesh Agricultural University, Mymensingh, $51+4 \mathrm{pp}$.

Fouad, A.M., El-Senousey, H.K., Yang, X.J. \& Yao, J.H. 2012. Role of dietary L-arginine in poultry production. Int. J. Poult. Sci. 11(11): 718-729.

Geraert, P.A., Leclerco, B. \& Larbier, M. 1987. Effects of dietary glucogenic amino acid supplementation on growth performance, body composition and plasma free amino acid levels in genetically lean and fat chickens. Reprod. Nutr. Dev. 27(6): 1041-1051.

Getu, A. \& Birhan, M.M. 2014. Chicken production systems, performance and associated constraints in North Gondar Zone, Ethiopia. J. Fisheries Livest. Prod. 2: (2) http://dx.doi.org/10.4172/23322608.1000115

Ghosh, S.C., Hossain, M. \& Saleque, M.A. 2009. Practices of bio-security in wet market of Bangladesh in response to highly pathogenic avian influenza. $6^{\text {th }}$ International Poultry Show and Seminar, WPSA-BB, p.105-110.

Hamra, C.F. 2010. An assessment of the potential profitability of poultry farms: A broiler farm feasibility case study. MS thesis, Agriculture and Natural Resources Systems Management, University of Tennessee at Martin, USA. 35 pp.

Hossain, M.M. \& Ali, M.S. 2009. Waste management in poultry farms and environmental protection in Bangladesh. $6^{\text {th }}$ Int. Poultry Show and Seminar, WPSA-BB, p.199-202.

Jones, R. 1984. A standard method for the dissection of poultry for carcass analysis. Technical note number 222. News Letter, 12: 18-19.

Karabozhilova, I., Wieland, B., Alonso, S., Salonen, L. \& Hasler, B. 2012. Backyard chicken keeping in the Greater London Urban Area: Welfare status, biosecurity and disease control issues. British Poult. Sci. 53(4): 421-430.

Kobbaduzzaman, M. 2000. Commercial Chicken Management Guide (in Bangla). Nazrul Printing Press, Badurtala, Bogra. 113pp.

Mengesha, M., Tamir, B. \& Dessie, T. 2011. Village chicken constraints and traditional management practices in Jamma District, South Wollo, Ethiopia. Livestock Res. Rur. Dev. 23 Article \#37. http://www.lrrd.org/lrrd23/2/meng23037.htm

Moreki, J.C., Nelson, K. \& Boitumelo, W. 2016. Assessment of management practices of Tswana chickens at North East District of Botswana. J. Anim. Sci. Vet Med. 1: 29-38.

Musa, W.I., Sa`idu, L., Kaltungo, B.Y., Abubakar, U.B. \& Wakawa, A.M. 2012. Poultry litter selection, management and utilization in Nigeria. Asian J. Anim. Vet. Adv. 6: 44-55.

NRC (National Research Council) 1994. Nutrient Requirements of Poultry (9th edn). National Academy Press, Washington, DC. 
Odemero, A.F. \& Oghenesuvwe, O. 2016. Mortality risk severity, associated factors and appropriate management options in poultry agribusiness in Delta State, Nigeria. Int. J. Agric. Ext. Rur. Dev. Studies 3(2): 1-14.

Olumayowa, O. \& Abiodun, O.O. 2011. Profit efficiency and waste management in poultry farming: The case of Egba Division, Ogun State, Nigeria. Int. J. Poult. Sci. 10: 137-142.

Shamsuddoha, M. 2010. Sustainable development of environment friendly commercial poultry industry in Bangladesh. http://ssrn.com/abstract=1702073.

Tsegaye, B., Gudina, T.V. \& Alemseged, H.N. 2014. Evaluation of management practices and marketing systems of village chicken in Ethiopia. Afr. J. Trop. Agric. 2(10): 105-110.

Weyuma, H., Singh, H. \& Megersa, M. 2015. Studies on management practices and constraints of back yard chicken production in selected rural areas of Bishoftu. J. Vet. Sci Technol. S12:003. doi:10.4172/2157-7579.1000S12-003

$$
--0--
$$

